\title{
Studies on the Influence of Growth Regulators and Chemicals on the Quality Parameters of Grape cv. 2A Clone
}

\author{
Shivaningapp Kumbar*, D.R. Patil, Kishore Kumar Das, G.S.K. Swamy, \\ N. Thammaiah, J. Jayappa and Kantesh Gandolkar
}
Department of Fruit Science, K.R.C. College of Horticulture, Arabhavi-591 218, University of Horticultural Sciences, Bagalkot-587 102, Karnataka, India
*Corresponding author

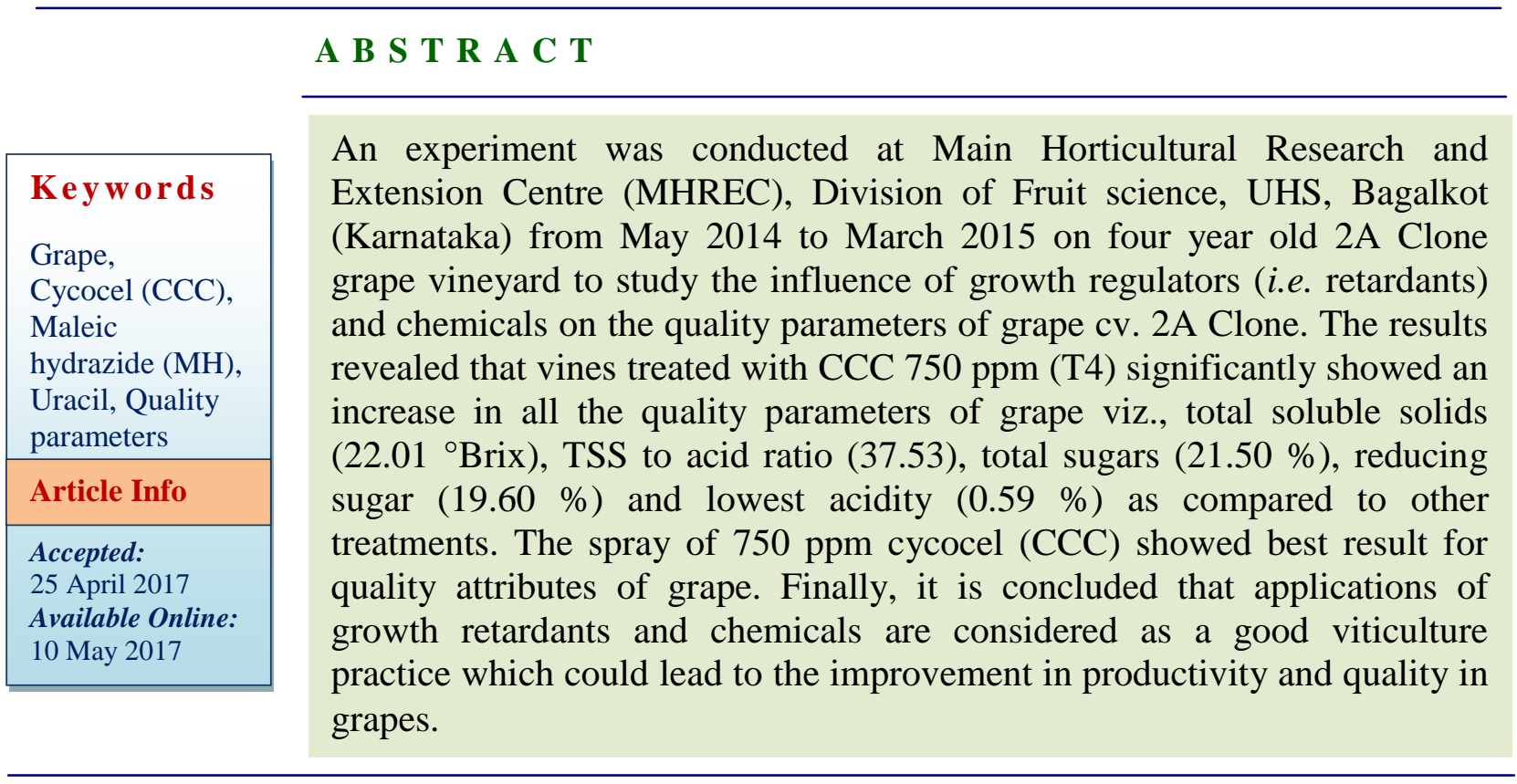

\section{Introduction}

Grape (Vitis vinifera L.) is an important and delicious subtropical fruit crop having its origin in Asia Minor. In India it is cultivated in an area of about 1.18 lakh ha with an annual production of 25.85 lakh tonnes. Grape cultivation in India acquires great significance due to its high productivity (21.8 $\mathrm{mt} / \mathrm{ha}$ ) compared to many other grape producing countries (Anon., 2014). Maharashtra occupies the largest area among the different Indian states and Karnataka stands second in grape production with a productivity of $(14.8 \mathrm{mt} / \mathrm{ha})$. It produces 3.02 lakh tonnes annually from an area of 0.20 lakh ha (Anon., 2014). Among many cultivars grown in India, Thompson Seedless is the leading variety and recently $2 \mathrm{~A}$ Clone is gaining popularity in Karnataka and also in other parts of India on account of its superior table and raisin quality. Plant growth retardants generally have great effects on expanding of elongation cells, where inhibition of GA synthesis rapidly causes reduction in shoot elongation and thereby 
increase in fruit quality attributes (Tanimoto, 1983).

A lot of work on growth regulators i.e. retardants and chemicals has been done singly on several varieties of grapes, whereas information on combined effect of growth retardants and chemicals in grape, especially 2A Clone cultivar is scanty. Hence present experiment was undertaken to find out the influence of growth regulators and chemicals on quality parameters in grape cv. 2A Clone.

\section{Materials and Methods}

A field experiment was conducted at Main Horticultural Research and Extension Centre (MHREC), Division of Fruit science, UHS, Bagalkot (Karnataka) from May 2014 to March 2015 on four year old 2A Clone grape vineyard. Vines were planted at $3.0 \mathrm{~m} \mathrm{x} 1.5 \mathrm{~m}$ apart and trained on ' $\mathrm{Y}$ ' system. The vines were back pruned (vegetative/foundation pruning) on 4th April, 2014 and for fruiting (reproductive/forward pruning) was performed on 10th October, 2014. Cultural practices were uniform for all the vines, irrespective of the treatments. Three growth regulators (retardants) and chemicals viz., CCC (Cycocel), MH (Maleic hydrazide) and Uracil were tried for their effect on quality parameters along with control (without spray). Fourteen treatments comprised of growth regulators (retardants), chemicals and their combinations along with control viz., T1 - Control i.e. without spray; T2 - CCC 250 ppm; T3 - CCC 500 ppm; T4 - CCC 750 ppm; T5 - Uracil 50 ppm; T6 - Uracil 100 ppm; T7 - MH 500 ppm; T8 - CCC 250 ppm + Uracil 50 ppm; T9 - CCC 250 ppm + Uracil 100 ppm; T10 - CCC 500 ppm + Uracil 50 ppm; T11- CCC 500 ppm + Uracil 100 ppm; T12 CCC 750 ppm + Uracil 50 ppm; T13 - CCC $750 \mathrm{ppm}+$ Uracil $100 \mathrm{ppm}$ and T14 - MH $500 \mathrm{ppm}+$ Uracil $100 \mathrm{ppm}$. This investigation was laid out in Randomized Block Design
(RBD) with three replications. The weather parameters viz., maximum and minimum temperature, relative humidity and average rainfall in Bagalkot were recorded in experimental location. The data was statistically analysed interpreted here.

\section{Preparation of growth regulators and chemicals solution}

In the present investigation, growth regulators includes growth retardants namely cycocel and maleic hydrazide. The formulations of all the growth regulators and chemicals at required concentrations were prepared by dissolving appropriate amounts of growth regulators and chemicals in small amount of water and then the volume was made upto one litre by adding water. First solution of higher concentration was prepared and later solutions of lower strength were prepared by diluting with water. Proper mixing of the chemicals was met with, to ensure uniform distribution of chemicals all over the solution (Table 1).

\section{Application of the growth regulators and chemicals solution}

The prepared growth regulators and chemical solutions of different concentrations were sprayed forty five days after foundation bud pruning (Back pruning) i.e. 19th May, 2014 to the vines with the help of sprayer during evening hours as per the treatments.

\section{Sampling of the bunches for recording observations}

Five bunches per vine were selected from the tagged canes which were used to estimate the quality parameters.

\section{Total soluble solids $\left({ }^{\circ}\right.$ Brix $)$}

Total soluble solids (TSS) content was recorded with the help of a hand refractometer and expressed in degree Brix. 


\section{Titratable acidity $(\%)$}

The acidity was determined in terms of tartaric acid by diluting the juice extracted from five gram of sample and filtered through muslin cloth and made up to known volume with distilled water $(100 \mathrm{ml})$. From this, five $\mathrm{ml}$ of aliquot was taken and titrated against standard $\mathrm{NaOH} \quad\left(\begin{array}{ll}0.1 & \mathrm{~N}) \\ \text { using } & \mathrm{a}\end{array}\right.$ phenolphthalein as indicator. The appearance of light pink colour was recorded as the end point. The values were expressed in terms of tartaric acid per cent titrable acidity of the fruits (Ranganna, 1977).

\section{TSS to acid ratio}

TSS to acid ratio was obtained by dividing TSS ( ${ }^{\circ}$ Brix) with acidity (\%) of corresponding fruits.

\section{Reducing sugar (\%)}

Reducing sugars in the berry preserved in 80 per cent alcohol was estimated as per the Dinitro salicylic acid (DNSA) method (Miller, 1972). A known volume of alcohol extract was taken (need not go for clarification in grapes) and allowed to evaporate the alcohol completely. Clear solution was taken for estimation of reducing sugar using DNSA-reagent by following above method, the values obtained were expressed as percentage by referring to the standard graph obtained with glucose.

\section{Total sugars (\%)}

The total sugar in the sample was estimated by same method as that of the reducing sugar after inversion (Anon., 1984). One $\mathrm{ml}$ of evaporated extract was taken and kept in boiling water till the alcohol completely evaporated and allowed it to cool. Then phenolphthalein indicator was added followed by $1 \mathrm{~N}$ sodium hydroxide till the solution turned to pink. Again $0.1 \mathrm{~N}$ hydrochloric acid was added to discolour the solution. Then Dinitro-salicylic acid (DNSA) method for estimation of reducing sugar was followed. The results obtained were expressed in terms of percentage.

\section{Non-reducing sugars (\%)}

The percentage of non-reducing sugars was determined by substracting the per cent reducing sugar from the per cent total sugar (Somogyi, 1952).

Non-reducing sugar $(\%)=$ Per cent total sugar - Per cent reducing sugar

\section{Results and Discussion}

The present investigation revealed that the influence of growth regulators and chemicals on the quality attributes. The results obtained during the course of investigation are presented in the present study.

In the present experiment, total soluble solids (TSS) of berries among the various treatments, the vines treated with CCC 750 ppm showed significantly highest TSS (22.01 ${ }^{\circ}$ Brix) over other treatments by reducing the acidity content. While control vines i.e without spraying recorded total soluble solids of $20.51{ }^{\circ}$ Brix. The lowest was recorded in vines treated with $\mathrm{MH} 500 \mathrm{ppm}\left(18.99{ }^{\circ} \mathrm{Brix}\right)$ which was on par with MH 500 ppm + uracil $100 \mathrm{ppm}\left(19.13{ }^{\circ}\right.$ Brix $)$ treatment (Table 2$)$. Similar results are in accordance with the results obtained by Looney (1981), Patil (1982) and Khajuria and Bakhshi (1984) also indicated effective results with CCC in improving the quality of grapes. The vines treated with CCC $750 \mathrm{ppm}$ recorded significantly least percentage of acidity of berries $(0.59 \%)$ due to high TSS content of the berries as compared to other treatments. While control vines i.e without spraying recorded the acidity of $(0.75 \%)$ and was on par with CCC $250 \mathrm{ppm}+$ uracil $100 \mathrm{ppm}$ 
$(0.75 \%)$ treatment. The highest acidity was observed in vines treated with MH $500 \mathrm{ppm}$ $(0.86 \%)$ which was on par with MH $500 \mathrm{ppm}$ + uracil $100 \mathrm{ppm}(0.84 \%)$ and uracil $50 \mathrm{ppm}$ $(0.83 \%)$ treatments (Table 2$)$. The identical results were reported by Bhat (1992) and Sehrawat et al., (1998) in Thompson Seedless grapes. Murthy (2014) also reported that spraying of CCC with $1000 \mathrm{ppm}$ at 21-25 days after April pruning increased the quality in grapes. Among the various concentrations of growth retardants and chemicals, the vines treated with CCC $750 \mathrm{ppm}$ improved the TSS to titratable acid ratio by recording significantly higher value (37.53) over other treatments. This was followed by CCC 750 ppm + uracil 100 ppm (34.50) and CCC 750 $\mathrm{ppm}+$ uracil $50 \mathrm{ppm}$ (32.50) concentrations. The MH 500 ppm concentration declined the ratio to the least (22.01) which was on par with $\mathrm{MH} 500 \mathrm{ppm}+$ uracil $100 \mathrm{ppm}$ (22.68) treatment (Table 2). Present findings are substantiated with the findings of Abd ElRhman (2010) and Bhat (1992) in Thompson Seedless grapes. The increased TSS to acid ratio might be due to increase in total soluble solids content and reduction in acid content of the berries and which actually makes the quality of grapes.

Table.1 Preparation of growth regulators and chemicals solution

\begin{tabular}{|c|c|c|c|c|}
\hline S. No. & $\begin{array}{l}\text { Growth regulators and } \\
\text { chemicals }\end{array}$ & $\begin{array}{c}\text { Concentration } \\
(\mathrm{ppm})\end{array}$ & $\begin{array}{l}\text { Quantity growth } \\
\text { regulators and } \\
\text { chemicals }(\mathrm{mg})\end{array}$ & $\begin{array}{l}\text { Required } \\
\text { water }(\mathrm{ml})\end{array}$ \\
\hline 1. & Water & - & - & 1000 \\
\hline 2. & $\mathrm{CCC}$ & 250 & 250 & 1000 \\
\hline 3. & $\mathrm{CCC}$ & 500 & 500 & - do- \\
\hline 4. & $\mathrm{CCC}$ & 750 & 750 & - do- \\
\hline 5. & Uracil & 50 & 50 & -do- \\
\hline 6. & Uracil & 100 & 100 & - do- \\
\hline 7. & Maleic hydrazide & 500 & 500 & - do- \\
\hline 8. & $\mathrm{CCC}+$ Uracil & $250+50$ & $250+50$ & - do- \\
\hline 9. & CCC + Uracil & $250+100$ & $250+100$ & -do- \\
\hline 10. & $\mathrm{CCC}+$ Uracil & $500+50$ & $500+50$ & - do- \\
\hline 11. & $\mathrm{CCC}+$ Uracil & $500+100$ & $500+100$ & -do- \\
\hline 12. & CCC + Uracil & $750+50$ & $750+50$ & - do- \\
\hline 13. & $\mathrm{CCC}+$ Uracil & $750+100$ & $750+100$ & - do- \\
\hline 14. & Maleic hydrazide + Uracil & $500+100$ & $500+100$ & -do- \\
\hline
\end{tabular}


Table.2 Total soluble solids, acidity and TSS to acid ratio in grape cv. 2A Clone (Vitis vinifera L.) as influenced by growth regulators and chemicals

\begin{tabular}{|c|c|c|c|}
\hline Treatments & Total soluble solids ( ${ }^{\circ}$ Brix $)$ & Acidity (\%) & TSS to acid ratio \\
\hline $\mathrm{T}_{1}$ - Control (without spray) & 20.51 & 0.75 & 27.48 \\
\hline $\mathrm{T}_{2}-\mathrm{CCC} 250 \mathrm{ppm}$ & 19.93 & 0.81 & 24.73 \\
\hline $\mathrm{T}_{3}-\mathrm{CCC} 500 \mathrm{ppm}$ & 20.69 & 0.73 & 28.34 \\
\hline $\mathrm{T}_{4}-\mathrm{CCC} 750 \mathrm{ppm}$ & 22.01 & 0.59 & 37.53 \\
\hline $\mathrm{T}_{5}$ - Uracil $50 \mathrm{ppm}$ & 19.47 & 0.83 & 23.56 \\
\hline $\mathrm{T}_{6^{-}}$Uracil $100 \mathrm{ppm}$ & 19.70 & 0.81 & 24.24 \\
\hline $\mathrm{T}_{7}-\mathrm{MH} 500 \mathrm{ppm}$ & 18.99 & 0.86 & 22.01 \\
\hline $\mathrm{T}_{8^{-}}$CCC $250 \mathrm{ppm}+$ Uracil $50 \mathrm{ppm}$ & 20.17 & 0.79 & 25.64 \\
\hline $\mathrm{T}_{9^{-}}$CCC $250 \mathrm{ppm}+$ Uracil $100 \mathrm{ppm}$ & 20.41 & 0.75 & 27.22 \\
\hline $\mathrm{T}_{10^{-}}$CCC $500 \mathrm{ppm}+$ Uracil $50 \mathrm{ppm}$ & 21.00 & 0.69 & 30.66 \\
\hline $\mathrm{T}_{11^{-}}$CCC $500 \mathrm{ppm}+$ Uracil $100 \mathrm{ppm}$ & 21.08 & 0.68 & 31.04 \\
\hline $\mathrm{T}_{12^{-}}$CCC $750 \mathrm{ppm}+$ Uracil $50 \mathrm{ppm}$ & 21.23 & 0.65 & 32.50 \\
\hline $\mathrm{T}_{13}$ CCC 750 ppm + Uracil 100 ppm & 21.48 & 0.62 & 34.50 \\
\hline $\mathrm{T}_{14}-\mathrm{MH} 500 \mathrm{ppm}+$ Uracil 100 ppm & 19.13 & 0.84 & 22.68 \\
\hline SEm \pm & 0.16 & 0.01 & 0.53 \\
\hline $\mathrm{CD}$ at $5 \%$ & 0.47 & 0.03 & 1.54 \\
\hline
\end{tabular}

CCC- Cycocel, MH- Maleic hydrazide 
Table.3 Total sugar, reducing sugar and non-reducing sugar content in grape cv. 2A Clone (Vitis vinifera L.) as influenced by growth regulators and chemicals

\begin{tabular}{|c|c|c|c|}
\hline Treatments & $\begin{array}{c}\text { Total sugar } \\
(\%)\end{array}$ & $\begin{array}{c}\text { Reducing sugar } \\
(\%)\end{array}$ & $\begin{array}{c}\text { Non-reducing sugar } \\
(\%)\end{array}$ \\
\hline $\mathrm{T}_{1^{-}}$Control (without spray) & 18.58 & 16.83 & 1.75 \\
\hline $\mathrm{T}_{2}-\mathrm{CCC} 250 \mathrm{ppm}$ & 17.80 & 16.45 & 1.35 \\
\hline $\mathrm{T}_{3}-\mathrm{CCC} 500 \mathrm{ppm}$ & 18.63 & 16.85 & 1.78 \\
\hline $\mathrm{T}_{4^{-}} \mathrm{CCC} 750 \mathrm{ppm}$ & 21.50 & 19.60 & 1.90 \\
\hline $\mathrm{T}_{5^{-}}$Uracil $50 \mathrm{ppm}$ & 17.62 & 16.30 & 1.32 \\
\hline $\mathrm{T}_{6^{-}}$Uracil $100 \mathrm{ppm}$ & 17.20 & 15.99 & 1.22 \\
\hline $\mathrm{T}_{7}-\mathrm{MH} 500 \mathrm{ppm}$ & 16.98 & 15.70 & 1.28 \\
\hline $\mathrm{T}_{8^{-}}$CCC $250 \mathrm{ppm}+$ Uracil 50 ppm & 17.83 & 16.58 & 1.25 \\
\hline $\mathrm{T}_{9^{-}} \mathrm{CCC} 250 \mathrm{ppm}+$ Uracil $100 \mathrm{ppm}$ & 18.35 & 16.79 & 1.56 \\
\hline $\mathrm{T}_{10^{-}}$CCC $500 \mathrm{ppm}+$ Uracil $50 \mathrm{ppm}$ & 18.50 & 16.95 & 1.55 \\
\hline $\mathrm{T}_{11^{-}}$CCC $500 \mathrm{ppm}+$ Uracil 100 ppm & 18.90 & 17.43 & 1.47 \\
\hline $\mathrm{T}_{12^{-}}$CCC $750 \mathrm{ppm}+$ Uracil $50 \mathrm{ppm}$ & 20.05 & 18.35 & 1.70 \\
\hline $\mathrm{T}_{13}$ CCC 750 ppm + Uracil 100 ppm & 20.53 & 18.70 & 1.83 \\
\hline $\mathrm{T}_{14-} \mathrm{MH} 500 \mathrm{ppm}+$ Uracil $100 \mathrm{ppm}$ & 17.15 & 15.76 & 1.39 \\
\hline SEm \pm & 0.22 & 0.09 & 0.16 \\
\hline $\mathrm{CD}$ at $5 \%$ & 0.63 & 0.27 & NS \\
\hline
\end{tabular}

CCC- Cycocel, MH- Maleic hydrazide, NS-Non-significant 
In the present study, the data on total sugar of berries was significantly influenced by various growth retardants and chemicals. Among the various concentrations, the vines treated with CCC $750 \mathrm{ppm}$ recorded significantly highest total sugars content in berries $(21.50 \%)$ followed by CCC $750 \mathrm{ppm}$ + uracil $100 \mathrm{ppm}(20.53 \%)$ and CCC 750 ppm + uracil 50 ppm (20.05\%) treatments. The lowest was recorded in vines treated with MH 500 ppm (16.98\%) which was on par with $\mathrm{MH} 500 \mathrm{ppm}+$ uracil 100 ppm (17.15 $\%)$ and uracil 100 ppm (17.20\%) treatments. CCC 750 ppm treatment recorded highest reducing sugar in berries $(19.60 \%)$ as compared to other treatments. This was followed by CCC $750 \mathrm{ppm}+$ uracil $100 \mathrm{ppm}$ $(18.70 \%)$ and CCC $750 \mathrm{ppm}+$ uracil $50 \mathrm{ppm}$ $(18.35 \%)$ treatments. The lowest was recorded in vines treated with $\mathrm{MH}, 500 \mathrm{ppm}$ $(15.70 \%)$ which was on par with MH 500 ppm + uracil 100 ppm (15.76\%). The nonreducing sugar content was found to be nonsignificant (Table 3). These are in confirmed with the results noted by Marchiori and Zanni (1973) in Cabernet Franc vines. Ahlawat and Daulta (1981) opined that cycocel at 500 and 1000 ppm improved berry set and quality of Kishmish Charni grapes. This might be due to high TSS and greater utilization and assimilation of total carbohydrates during flower bud initiation and differentiation in cycocel treated vines.

In conclusion the Vines treated with CCC 750 ppm produces the good quality grapes for attracting consumers and preparing good quality raisins, along with higher yield than the control vines (without spray). In both table and raisin grapes along with higher yield, quality characters are also more important. From the present investigation, it is concluded that, applications of growth retardants and chemicals are considered as a good viticulture practice which could lead to the improvement in productivity and quality in grapes.

\section{References}

Abd El-Rhman, I.E. 2010. A study on some treatments which mitigate drought effects on Barrani grapevines cv. $J$. Appl. Sci. Res., 6(6): 704-711.

Ahlawat, V.P. and Daulta, B.S. 1981. Effect of CCC and SADH on fruit set and quality of Kishmish Charni grape (Vitis vinifera L.). Haryana J. Hort. Sci., 10: 42-44.

Anonymous. 2014. Indian horticulture data base, http://www.nhb.gov.in.

Anonymous. 1984. Official methods of analysis, Ed. Sioney Williams, Association official analytical Virginia, 14th edition, pp: 423-462.

Bhat, V.R. 1992. Studies on back pruning, growth retardants and pinching in some cultivars of grape (Vitis vinifera L.). Ph.D. thesis, University of Agricultural Sciences, Dharwad.

Khajuria, H.N. and Bakhshi, J.C. 1984. Responsiveness of perlette grapes (Vitis vinifera $\mathrm{L}$.) to the application of $\mathrm{CCC}$, NMC, TIBA, coconut milk and girdling treatments. Indian Agric., 28: 255-260.

Looney, N.E. 1981. Some growth regulators and cluster thinning effects on berry set and size, berry quality, and annual productivity of De Chaunac grapes. Vitis, 20: 22-35.

Marchiori, G. and Zanni, L. 1973. Vegetative and productive control in grapevines by chemical (Cycocel) and mechanical (ringing) treatments. Informatore Agrario., 29(23): 12677-12679.

Miller, G.C. 1972. Use of dinitro salicylic acid reagent for determination of reducing sugar. Annual Chem.., 31: 426-428.

Murthy, B.N.S. 2014. Production technologies recommended for tropical fruit crops. ICAR-DAC Interface Meeting, pp. 33-36. 
Patil, D.R. 1982. Studies on promotion of fruitfulness in Thompson Seedless grapevine (Vitis vinifera L.). M.Sc. thesis, University of Agricultural Sciences, Bangalore.

Ranganna, S. 1977. Manual of analysis of fruit and vegetable products, Tata McGraw- Hill publishing company limited, New Delhi, India.

Sehrawat, S.K., Daulta, B.S., Dahiya, D.S. and Bhardwaj, R. 1998. Effect of growth retardants on growth, yield and fruit quality in grape (Vitis vinifera L.) cv. Thompson Seedless. Int. J. Trop. Agric., 16(1/4): 179-184.

Somogyi, M.S. 1952. Notes on sugar determination. J. Bio. Chem., 200: 24.

Tanimoto, E. 1983. Gibberellin-dependent not elongation in Lactuca sativa: recovery from growth retardant suppressed elongation with thickening by low concentration of GA3. Plant Cell Physiol., 28: 963-973.

\section{How to cite this article:}

Shivaningapp Kumbar, D. R. Patil, Kishore Kumar Das, G. S. K. Swamy, N. Thammaiah, J. Jayappa and Kantesh Gandolkar. 2017. Studies on the Influence of Growth Regulators and Chemicals on the Quality Parameters of Grape cv. 2A Clone. Int.J.Curr.Microbiol.App.Sci. 6(5): 2585-2592. doi: https://doi.org/10.20546/ijcmas.2017.605.291 